\title{
Investigation on Trichothecene-Stimulated Lipid Peroxidation and Toxic Effects of Trichothecenes in Animals
}

\author{
By E. Karppanen, A. Rizzo, L. Saari, S. Berg and H. Boström. \\ National Veterinary Institute, Helsinki, Finland.
}

\begin{abstract}
Karppanen, E, A. Rizzo, L. Saari, S. Berg and H. Boström: Investigation on Trichothecene-stimulated Lipid Peroxidation and Toxic Effects of Trichothecenes in Animals. Acta vet. scand. 1989, 30, 391-399. - Three experiments were performed with mice intoxicated with trichothecene-contamined feed or directly into the stomach. Lipid peroxidation was estimated by the TBA value from liver samples, but since such a test seldom provided reliable results, lipid hydroperoxides and total carbonyl were also analyzed. The formation of aldehydes and ketones was compared in vivo and in vitro. The same investigations were conducted on chickens, rainbow trouts and numerous fur animals suspected of chronic intoxication by trichothecenes. The vitamin A concentration was used as a parameter to detect alterations caused in chickens by trichothecenes. Our investigation provided evidence that lipid peroxidation is associated with trichothecene poisoning. The T-2 toxin, even in small concentrations, seems to induce strong lipid peroxidation. When DON and 3-AcDON were given together at a dosage of $180 \mu \mathrm{g} / \mathrm{kg}$ feed, 1 week's feeding caused clear lipid peroxidation in mice. Particular attention should be paid to the fact that mycotoxins may already be present in the feed before any experiment is conducted.
\end{abstract}

Deoxynivalenol; T-2 toxin; vitamin A.

\section{Introduction}

The trichothecene mycotoxins produced by Fusarium molds are highly toxic to animals and humans. They are specific and potent inhibitors of protein and DNA synthesis in animal cells (Ueno et al. 1973) through the inactivation of SH-enzymes by binding with thiol groups (Ueno \& Matsumoto 1975). Ueno et al. (1973) have investigated the inhibitory effects of trichothecenes on protein and DNA synthesis in whole-cell and cellfree systems. It has been suggested that T-2 toxin and others of the same group (type A) have a higher affinity for the biomembrane structure than nivalenol, fusarenon-X etc. (the type B). In vitro experiments have shown that the hemolysis of rat erythrocytes caused by T- 2 toxin and that caused by a free radical mechanism are very similar (Segal et al. 1983). It has also been demonstrated that T-2 toxin markedly stimulates lipid peroxidation specifically in the liver of rats, as estimated by the TBA value (Tsuchida et al. 1984). It has been concluded that the T-2 toxin primarily causes damage to the membrane systems of liver cells, and that peroxidation of the membrane lipids is secondarily stimulated.

When lipid peroxidation is stimulated by toxic agents, the peroxidation reaction results in disturbances in the functioning and structure of the cell membranes. The nonenzymic autotoxidation of the polyunsaturated fatty acids produces a complex mixture of pro- 
ducts, alkenals, 2-alkenals, 4-hydroxyalkenals and malonaldehyde (Esterbauer et al. 1982). The aldehydes have biological activity: for example, 4-hydroxyoctenal can strongly inhibit various enzyme reactions, and 4-hydroxypentenal has a strongly inhibitory effect on DNA and protein synthesis and reacts rapidly with thiols such as cysteine and glutathione.

Many features of the biological reactivities of trichothecenes are very similar to those produced by the compounds generated by lipid peroxidation. When the trichothecenes trigger lipid peroxidation, their toxic effect is enhanced and can continue even after the toxins have been metabolized and excreted. Detection of the presence of lipid peroxidation in intoxicated animals could provide valuable complementary evidence in addition to other data. The purpose of this investigation was to determine whether lipid peroxidation occurs in animals treated with different types of trichothecene, to test the available methodology and to develop new ones.

\section{Materials and methods}

Type NMRI mice, 20-30 $\mathrm{g}$ in weight, were used in the experiments. In the first experiment (I) each animal group consisted of 5 mice and the experiment lasted 7 days. The mice were fed with feed supplemented with T-2 and HT-2 toxin. The feed of groups VII and VIII (Table 1) were analyzed for the presence of 7 trichothecenes: only deoxynivalenol (DON) and 3-acetyldeoxynivalenol (3AcDON) were detected as natural contaminants. Butylhydroxyanisole (BHA) and $\alpha$ tocopherol were added to the feed used in the experiment in order to obtain information about their possible protective effect against lipid peroxidation. The second experiment (II) was performed on mice, each group comprising of 10 animals. Each mouse received DON and T- 2 toxin in a $4 \%$ etha- nol solution, administred by a probe directly into the stomach. The mice were treated with $4 \mathrm{mg} / \mathrm{kg}$ and $3 \mathrm{mg} / \mathrm{kg} \mathrm{T}-2$ toxins, and sacrified after 4 and $24 \mathrm{~h}$ respectively.

In the third experiment (III) 2 groups of 10 mice were fed with contaminated feed. One of the feeds was supplemented with DON and the other with T-2 toxin. Feeding was continued for 7 days. Experimental data are given in the respective tables. After sacrifice the liver and kidneys of the mice were removed and washed with a $0.9 \% \mathrm{NaCl}$ solution containing $0.5 \%$ EDTA. The samples were rapidly dried on filter paper, frozen in liquid nitrogen and stored at $-45^{\circ} \mathrm{C}$ until analysis. The other animals were brought to our Institute for investigation purposes. Ten chickens were received alive and their liver was treated in the same way as those of the mice. The livers of rainbow trouts and fur animals were removed at the farms, deep frozen immediately, and stored at $-20^{\circ} \mathrm{C}$ until analysis. The data concerning rainbow trouts and fur animals were not complete as it was not possible to obtain full information about the background of the samples. Determination of the TBA value, lipid hydroperoxides and total carbonyl were performed on the same homogenized sample. The accumulation of vitamin $\mathrm{A}$ in the liver has been used in our laboratory as a parameter in the investigation of animals intoxicated by trichothecenes (Karppanen \& Rizzo 1983).

\section{Determination of TBA value}

The TBA value or TBARS (thiobarbituric acid reactive substances) was estimated by a method (Ribarov \& Benov 1981) modified for liver samples. The liver was homogenized and $1 \mathrm{~g}$ of the homogenate diluted to 12 $\mathrm{ml}$ in $0.9 \% \mathrm{NaCl}$ solution. $6 \mathrm{ml}$ of the suspension were supplemented with $0.1 \mathrm{ml}$ of Triton-X $100(10 \%)$ and vigorously stirred. 8 $\mathrm{ml}$ of a solution prepared by mixing $75 \mathrm{ml}$ of 
$30 \%$ trichloracetic acid, $25 \mathrm{ml}$ of $0.6 \%$ TBA and $3 \mathrm{ml}$ of $4 \%$ butylhydroxytoluene in ethanol was added. After filtering, $9 \mathrm{ml}$ of the filtrate was combined with $6 \mathrm{ml}$ of the TBA solution. The reaction screw-cap tubes were heated for $15 \mathrm{~min}$ in boiling water, cooled down and washed with $6 \mathrm{ml}$ of chloroform. After centrifuging, the absorbance of the water phase was read at $530 \mathrm{~nm}$ in a 1 $\mathrm{cm}$ or $2.5 \mathrm{~cm}$ cuvette against a blank prepared simultaneously with the sample. The calibration curve was made with standard malonaldehydediethylacetal.

\section{Determination of lipid hydroperoxides}

A modification of the method of Pesh-Imam (1978) was used in this study for the determination of the lipid peroxides. About $3 \mathrm{~g}$ of homogenized liver were extracted with $20 \mathrm{ml}$ of chloroform-methanol (1:1), filtered through chemically clean cotton $(0,2 \mathrm{~g})$ in a $50 \mathrm{ml}$ glass stoppered Erlenmayerflask containing $5.5 \mathrm{~g}$ of anhydrous sodium sulphate, mixed and left to stand for $15 \mathrm{~min} .350 \mathrm{mg}$ of activated carbon was added, mixed and let to stand for $30 \mathrm{~min}$. The suspension was filtered through filter paper (Whatman 42). The reagent was prepared by dissolving 250 $\mathrm{mg}$ of dimethylphenylendiamine $\cdot 2 \mathrm{HCl}$ (Fluka) in $4 \mathrm{ml} \mathrm{H}_{2} \mathrm{O}, 0.15 \mathrm{ml}$ of acetic acid and $21 \mathrm{ml}$ of methanol daily, and stored at $+4^{\circ} \mathrm{C}$ protected from light. $4 \mathrm{ml}$ of the sample extract were supplemented with $0.2 \mathrm{ml}$ of the reagent solution, mixed and left in the dark for $30 \mathrm{~min}$. The sample was read against a blank at $520 \mathrm{~nm}$, and compared with a calibration curve made with standard solution of $\mathrm{H}_{2} \mathrm{O}_{2}$ in chloroform-methanol $(1: 1)$, treated in the same way as the sample and prepared at the same time. The concentration of the $\mathrm{H}_{2} \mathrm{O}_{2}$ standard solution was determined by iodometric titration.
Determination of total carbonyl compounds The method of McDonald \& Hultin (1987) was used for determining total carbonyl compounds. $2 \mathrm{~g}$ of homogenized liver were supplemented with $8 \mathrm{ml}$ of trichloroacetic acid (TCA) $20 \%$, left to stand for $15 \mathrm{~min}$, and centrifuged (at $4000 \mathrm{rpm}$ ) for $10 \mathrm{~min} .3$ $\mathrm{ml}$ of an aqueous saturated solution of 2,4dinitrophenylhydrazine, purified by hexane extraction (4 times), were added to $2 \mathrm{ml}$ of the sample and allowed to react for $15 \mathrm{~min} .3$ $\mathrm{ml}$ of hexane were used to extract the sample by Vortex for $3 \mathrm{~min}$. After centrifuging for 5 min (at $3000 \mathrm{rpm}$ ) the absorbance of the hexane layer was read at $340 \mathrm{~nm}$. The results were compared with a standard curve constructed using hexanale. The curve was linear over the range from 1 to $100 \mu \mathrm{g}$ of hexanale in $3 \mathrm{ml}$ hexane.

\section{In vitro experiment}

Lipid peroxidation was stimulated in mice liver microsomes prepared as described by Slater \& Sawyer (1971) and Benedetti et al. (1980). The incubation procedure and preparation of the 2,4-dinitrophenylhydrazones were carried out according to Esterbauer et al. (1982), with the difference that the livers were extracted with 3 times $80 \mathrm{ml}$ of chloroform. The extract was evaporated on a Rotavapor, redissolved in a few milliliters of ethylacetate, and analyzed by thin-layer chromatography in comparison with a control. The plate was run twice $5 \mathrm{~cm}$ from the seeding point, and once up to $12 \mathrm{~cm}$ using dichlormethane as developer.

\section{Results}

The results of the first experiment (I) are shown in Table 1. The change in weight concerns the groups consisting of 5 mice. 
Table 1. TBA value in the liver of mice fed with trichothecenes. Experiment $I$.

\begin{tabular}{|c|c|c|}
\hline Group No. Feed & Change in weight, $g$ & TBA-value $\mu \mathrm{g} / \mathrm{g}$ live \\
\hline I Control & +20 & 1.8 \\
\hline \multicolumn{3}{|l|}{ II $228 \mu \mathrm{g} \mathrm{T}-2$ toxin $/ \mathrm{kg}$, } \\
\hline 3 days & +11 & $2.6^{*}$ \\
\hline \multicolumn{3}{|l|}{$912 \mu \mathrm{g} \mathrm{HT}-2$ toxin $/ \mathrm{kg}$} \\
\hline \multicolumn{3}{|l|}{4 days } \\
\hline \multicolumn{3}{|l|}{ III Same as group II + } \\
\hline $3.33 \mathrm{BHA} / \mathrm{kg}$ & +17 & 11.0 \\
\hline IV $3.33 \mathrm{~g} \mathrm{BHA} / \mathrm{kg}$ & +9 & 1.2 \\
\hline \multicolumn{3}{|l|}{ V Same as grup II + } \\
\hline $1.0 \mathrm{~g} \alpha$-tocopherol $/ \mathrm{kg}$ & +12 & $1.6^{*}$ \\
\hline VI $1.0 \mathrm{~g} \alpha$-tocopherol $/ \mathrm{kg}$ & +10 & 1.4 \\
\hline \multicolumn{3}{|l|}{ VII $3060 \mu \mathrm{g}$ DON + } \\
\hline $283 \mu \mathrm{g} 3 \mathrm{AcDON} / \mathrm{kg}$ & -4 & 6.3 \\
\hline \multicolumn{3}{|l|}{ VIII $82 \mu \mathrm{g} \mathrm{DON+}$} \\
\hline $98 \mu \mathrm{g} \mathrm{3AcDON} / \mathrm{kg}$ & +16 & 5.2 \\
\hline
\end{tabular}

* Yellow or orange colour.

The large amount of DON and 3-AcDON made the mice refuse the feed and resulted in a decrease in weight (group VII). The samples from group II and $\mathrm{V}$ gave a yellow colour when analyzed for TBA. The highest TBA values were obtained for groups III, VII and VIII when compared to IV, VI and the control. It was apparent already during the first experiment that the normal methods used to determine the TBA value did not give reliable results because some of the samples were yellow and orange, instead of the normal pink-purple colour. When the experiment was repeated for the second time, those samples expected to have high peroxide values turned yellow when the reaction for the determination of TBA was carried out. The same results were obtained with samples from the in vitro induced lipid peroxidation. The experiment confirmed that the addition of $0.5 \mathrm{mg}$ of hydrogen peroxide to the reaction mixture markedly decreased the spectrophotometric absorbtion of the sample. Concentrations ranging from 1 to $10 \mathrm{mg}$ of hydrogen peroxide produced an orange and yellow colour. When the sample was supplemented with BHA in amounts ranging from 1 to $10 \mathrm{mg}$ and a known amount of hydrogen peroxide, the absorption increased but was markedly lower than that for the corresponding malonylaldehyde standard without hydrogen peroxide. The solutions in this case were orange. It would appear that if BHA is added to the feed of mice, it cannot protect the animals from lipid peroxidation. In this case, however, (Table 1, group III) it did protect the TBA from oxidation. $\alpha$-tocopherol did not protect the animals or the TBA reagent (Table 1, group V). It would also appear that factors other than peroxides can interfere in the reaction, and hence the TBA analysis was combined with the hydroperoxide determination. The results of the second experiment (II) are given in Table 2 as $\mu \mathrm{g} / \mathrm{g}$ of liver or kidney.

The TBA value was high and the peroxide level increased after $4 \mathrm{~h}$ in the liver and kidney of mice treated with DON. The liver and kid- 
Table 2. TBA value and lipid hydroperoxide concentrations in the liver and kıdney of mice treated with trichothecenes. Experiment II.

\begin{tabular}{lcc}
\hline After $4 \mathrm{~h}$ & TBA value, $\mu \mathrm{g} / \mathrm{g}$ & Peroxides, $\mu \mathrm{g} / \mathrm{g}$ \\
\hline Control group, liver & 1.2 & 3.4 \\
Group I, DON, liver & 19.8 & 10.0 \\
Group III, T-2, liver & $2.6^{*}$ & 11.2 \\
Control group, kidney & 2.6 & 6.8 \\
Group I, DON, kidney & 3.9 & 13.8 \\
Group III, T-2, kidney & $5.0^{*}$ & 15.3 \\
After 24 h & & \\
Group II, DON, liver & $1.0^{*}$ & 3.4 \\
Group IV, T-2, liver & $5.6^{*}$ & 7.5 \\
Group II, DON, kidney & 2.4 & 4.6 \\
Group IV, T-2, kidney & 3.2 & 4.8 \\
\hline
\end{tabular}

* Yellow or orange colour

Control group: $0.5 \mathrm{ml} \mathrm{4 \%}$ ethanol

Group I: $\quad 200 \mu \mathrm{g}$ DON $/ 0.5 \mathrm{ml} 4 \%$ ethanol $(10 \mathrm{mg} / \mathrm{kg}), 4 \mathrm{~h}$.

Group II: same as group I; $24 \mathrm{~h}$.

Group III: $\quad 80 \mu \mathrm{g} \mathrm{T}-2$ toxin $/ 0.5 \mathrm{ml} .4 \%$ ethanol $(4 \mathrm{mg} / \mathrm{kg}), 4 \mathrm{~h}$.

Group IV: $\quad 60 \mu \mathrm{g} \mathrm{T}-2$ toxin $/ 0.5 \mathrm{ml} .4 \%$ ethanol $(3 \mathrm{mg} / \mathrm{kg}), 24 \mathrm{~h}$.

ney samples from mice treated with T-2 toxin produced an orange and yellow colour when analyzed for the TBA value. The 24-h liver samples of mice treated with $\mathrm{T}-2$ or DON also turned yellow during the TBA analysis.

The aldehydes and ketones produced during the lipid peroxidation process were determined. A reference control and a positive sample picture were obtained by inducing in vitro peroxidation in mice liver microsomes. The samples clearly differed from the controls and, according to thin layer chromatography, resulted in the formation of $15 \mathrm{com}$ pounds against 3 for the controls. The liver of ill animals that were expected to be positive for the presence of ketonic compounds gave the same picture as obtained in the in vitro control test. A more suitable and sensitive method was needed for our samples. In experiment III the liver and kidney were analyzed' for TBA value, lipid hydroperoxides and total carbonyl. The values are given in Table $3 \mathrm{as} \mu \mathrm{g} / \mathrm{g}$ of liver or kidney.

The data in Table 3 indicate that there were no differences between the control and the treated groups. When the mice were sacrified even the control group were found to have small intrapulmonar haemorrhagic areas. The group fed with T-2 had haemorrhage in the thoracic cavity, and also had pale and very soft livers compared to the controls. The control feed was found to contain DON $20 \mu \mathrm{g} / \mathrm{kg}$ and T-2 toxin $125 \mu \mathrm{g} / \mathrm{kg}$. All the mice had been fed with this feed prior to the experiment and had therefore been exposed for a prolonged time to trichothecenes and especially to T-2 toxin. When group II was fed for seven days with feed containing $300 \mu \mathrm{g}$ of $\mathrm{T}-2 / \mathrm{kg}$ the mice developed haemorrhaging in the thoracic cavity. This occurred again when the experiment was repeated a second time.

The results of an investigation (IV) conduc- 
Table 3. TBA value, lipid hydroperoxide and total carbonyl concentrations in the liver and kidney of mice fed with trichothecenes. Experiment III.

\begin{tabular}{lccc}
\hline & TBA-value $\mu \mathrm{g} / \mathrm{g}$ & Peroxides $\mu \mathrm{g} / \mathrm{g}$ & Total carbonyl $\mu \mathrm{g} / \mathrm{g}$ \\
\hline Control, liver & $0^{*}$ & 10.1 & 6.1 \\
Group I, DON, liver & $0^{*}$ & 11.2 & 4.0 \\
Group II, T-2, liver & $0^{*}$ & 8.6 & 5.5 \\
Control, kidney & 2.2 & 5.2 & 3.5 \\
Group I, DON, kidney & $0^{*}$ & 5.0 & 4.5 \\
Group II, T-2, kidney & $1.8^{*}$ & 4.5 & 5.0 \\
\hline
\end{tabular}

$0^{*}$ Yellow colour

Group I: $300 \mu \mathrm{g}$ DON $/ \mathrm{kg}$ feed

Group II: $300 \mu \mathrm{g} \mathrm{T}-2$ toxin $/ \mathrm{kg}$ feed

ted on young chickens are given in Table 4. Five samples were analysed, each consisting of 2 liver homogenates. The chickens did not show any symptoms of illness, but they gradually started to die after they had begun to lay eggs. Since comprehensive inspection of the animals did not reveal any disease, attention turned to the possibility that chickens had died because they had been fed for an extended period with feed containing small amounts of trichothecenes. According to Table 4, the chicken livers contained large amounts of vitamin A.

The level of hydroperoxides in the chicken livers was markedly higher than that in the mice fed or treated with trichothecenes. In this case, too, the sample analyzed for the TBA value turned yellow.
The highest level of peroxides was found in the liver of rainbow trouts. The level of peroxides was high, $100-200 \mu \mathrm{g}$ per gram liver, even in cases where the fish did not show any symptoms of illness. The highest amount was found in the liver of a rainbow trouts weighing $130-200 \mathrm{~g}$, brought in for investigation of the cause of death. Their livers were pale, the spleens enlarged and sanguineous, and the last tract of the intestines haemorragic. The peroxide concentration in these fish was $445 \mu \mathrm{g} / \mathrm{g}$, the TBA value $4 \mu \mathrm{g} / \mathrm{g}$ (orange colour), and the total carbonyl $3 \mu \mathrm{g} / \mathrm{g}$ liver. The total carbonyl content in animal liver is usually low. Despite this, some minks have been found with unusually high total carbonyl contents, 36-38 $\mu \mathrm{g} / \mathrm{g}$ liver. All of these minks had serious liver damage, mild or se-

T able 4. TBA value, lipid hydroperoxide, total carbonyl and vitamin A concentrations in chickens liver.

\begin{tabular}{lcccc}
\hline $\begin{array}{l}\text { Sample } \\
\text { no. }\end{array}$ & $\begin{array}{c}\text { TBA value, } \\
\mu \mathrm{g} / \mathrm{g}\end{array}$ & $\begin{array}{c}\text { Peroxides, } \\
\mu \mathrm{g} / \mathrm{g}\end{array}$ & $\begin{array}{c}\text { Total carbonyl, } \\
\mu \mathrm{g} / \mathrm{g}\end{array}$ & $\begin{array}{c}\text { Vitamin A, } \\
\text { USP } / \mathrm{g}\end{array}$ \\
\hline 1 & $0^{*}$ & 69.5 & 5.0 & 23333 \\
2 & $0^{*}$ & 59.0 & 5.3 & 18500 \\
3 & $0^{*}$ & 58.3 & 6.9 & 17167 \\
4 & $0^{*}$ & 66.5 & 3.4 & 18833 \\
5 & $0^{*}$ & 62.8 & 6.3 & 17334 \\
\hline
\end{tabular}

0* Yellow colour 
rious kidney damage, strong intestinal inflammation with haemorraging, and in one case ulcus. Numerous raccoon dogs and farm foxes with liver damage and ulcus were examined in the study, but their total carbonyl content was less than $10 \mu \mathrm{g} / \mathrm{g}$ liver.

\section{Discussion}

The experiment conducted on mice did not give the result expected, most probably because the control feed was already contaminated with trichothecenes and the animals were fed with this feed over a period of a few weeks. It is very difficult to obtain uncontaminated feed and suitable control animals. DON is present in nearly all and 3-AcDON in many of the Finnish cereals and feeds (Hintikka et al. 1987). This can affect the physiological condition of animals when they are exposed to trichothecenes for prolonged periods of time, and hence give unreliable results.

Another conclusion that can be drawn is that the physiological condition of animals will deteriorate if they receive small amounts of $\mathrm{T}-2$ toxin daily. If the animals suddenly receive higher concentrations of T-2 toxin then their health will seriously deteriorate and may even result in death.

The most disappointing finding was the fact that the results of the TBA analyses were not, in most cases, correlated with the lipid peroxidation process, thus proving the limitations of this method. Segal et al. (1983) have claimed that yellow compounds interfere with determination of the TBA value. A report published in 1962 claimed that several disturbances can occur in the malonaldehyde-TBA reaction (Tarladgis et al. 1962). The study indicated that TBA was oxidized when heated in the presence of an oxidizing agent. Buthylated hydroxy-toluene (BHT) has been used in some cases to protect TBA from oxidation (McDonald \& Hultin 1987). In our experiments we found that BHA cannot prevent oxidation of TBA when liver samples are analyzed. Under suitable conditions, however, the TBA method can give indicative information about the peroxidation in lipids. In fact it was possible to obtain a significant increase in the TBA value even in the case of small amounts of DON and 3-AcDON.

Since one of the aims of this work was to find suitable methods for the estimation of lipid peroxidation in animal tissues, other methods for determining the TBA value were also tested (Uchiyama \& Mihara 1978). In Uchiyama's method malonaldehyde reacts with TBA to produce, when heated in the presence of phosphoric acid of a specific $\mathrm{pH}$, a pink-purple colour. It was not possible to measure the absorbtion of our liver samples owing to the strong brown colour that developed in the solution when reacted with TBA. In the publication in question the authors have used experimental conditions where the animal could be exanguinated before sampling and the tissues were not damaged. For practical reasons, exanguination was not possible with our samples (e.g. fur animals, rainbow trout etc.) and the tissues are often damaged by toxins and/or lipid peroxidation. If the liver tissue shows signs of macroscopic damage then the sample for the determination of peroxides will result in a brown solution or brown precipitate, instead of the normal violet-purple colour.

Very high amounts of vitamin A have also been reported in mink livers (Lindberg et al. 1985) and sometimes in farm foxes, too. In most of the foxes suspected to be intoxicated by trichothecenes the concentration of vitamin A in liver decreased below $50 \mathrm{USP} / \mathrm{g}$ liver. The reason for this phenomenom is unknown.

The total carbonyl analyses were expected to give more accurate information about the 
peroxidation process. However, an experiment in vitro represents very different conditions from those in the liver of living animals. The compounds which are generated by lipid peroxides are removed from the liver by the circulating blood, and some of them react very quickly with thiol groups (Conroy et al. 1975). According to Esterbauer (1982), the oxidation of arachidonic, linoleic and linoleinic acids produces n-hexanal and 4-hydroxynonenal as major compounds. The 4hydroxyalkenals and 2-alkenals are very reactive substances, and can also react in small concentrations with cysteine, glutathione, HS-CoA and proteins or enzymes containing - $\mathrm{SH}$ groups. The toxicological properties of trichothecenes and the products originating from lipid peroxidation are very similar, and it may be that they can exert synergistic effect when both are present. Nine different trichothecenes have been identified and quantified in Finnish feeds. On occasions 5 different trichothecenes have even been identified in the same feed. Different toxins, different concentrations and different combinations of these toxins can cause a wide range of symptoms and diseases in animals. In the case of animals which have been exposed to trichothecenes, the lipid peroxides and the complex group of compounds generated by them can produce manifold symptoms and effects which are very difficult to elucidate. When lipid peroxidation exerts its damiging effect on cells and cell constituents, and the process continues in an autocatalytic way as a free radical chain reaction, even mild toxic conditions can lead to disturbances in the organism of the animals. It is suspected that long-term exposure to trichothecenes in particular can, for instance, produce changes in fur quality, serious skin damage, abnormal accumulation of fat under the skin or in the abdominal cavity, disturbances of the central nervous system, changes in the structure of the shell of hen eggs, high embryo and newborn mortality and total sterility.

Our investigation has provided enough evidence to assume that lipid peroxidation is associated with poisoning and long term feeding with trichothecenes. Small amounts of DON and $3 A c D N$ were found to increase the TBA value in this investigation. Further work is needed in order to determine the limits and toxic effect of mycotoxins on different kind of animals, because unknown mycotoxins or other compounds may be present in feed.

\section{Acknowledgement}

Maire Siberg is gratefully thanked for technical assistance.

\section{References}

Benedettı A, Comportı M, Esterbauer $H$ : Identification of 4-hydroxynonenal as a cytotoxic product originating from the peroxidation of liver microsomal lipids. Biochim. Biophys. Acta 1980, 620, 281-296.

Conroy PJ, Nodes JT, Slater TF, White GW: Carcinostatic activity of 4-hydroxy-2-penten-1-al against transplantable murine tumour lines. Europ. J. Cancer 1975, 11, 231-240.

Esterbauer $H$ : Aldehydic products of lipid peroxidation. In: Free radicals, lipid peroxidation and cancer. Eds. D.C.H. McBrien \& T.F. Slater. Academic Press, London, New York, Paris, San Diego, San Francisco, São Paulo, Sydney, Tokyo, Toronto 1982, p. 101-122.

Esterbauer H, Cheeseman KH, Dianzanı MU, Poli $G$, Slater TF: Separation and characterization of the aldehydic products of lipid peroxidation stimulated by ADP- $\mathrm{Fe}^{2+}$ in rat liver microsomes. Biochem. J. 1982, 208, 129-40.

Hıntıkka E-L, Saarı L, Berg S, Rizzo A, Karppanen $E$ : Occurrence of trichothecenes in feed and cereals in Finland. Mycotoxin Research. In press.

Karppanen E, Rizzo A: Disturbances of vitamin A metabolism in animals. Acta vet. scand. 1983, 24, 524-527. 
Lindberg L-A, Grohn Y, Karppanen E: Massive 11pid occumulation in mınk liver stellate cells may be caused by Fusarium mycotoxins in the feed. Acta vet. scand. 1985, 26, 423-424.

McDonald RE, Hultın HO: Some characteristics of the enzymic-lipid peroxidation system in the microsomal fraction of flounder skeletal muscle. J. Food Sci. 1987, 52, 15-21.

Pesh-Iman M, Willis RJ, Recknagel RO: Red cell damage induced by peroxidized microsomes; The relationship between hemolytic activity and peroxide content. J. Environ. Sci. Health 1978, C13, 81-95.

Rıbarov SR, Benov LC: Relationship between the hemolytıc action of heavy metals and lipid peroxidation. Biochim. Biophys. Acta 1981, 640, 721726.

Segal R, Milo-Goldzwelg I, Joffe AZ, Yagen B: Trichotheceneinduced hemolysis. Toxic Appl. Pharm. 1983, 70, 343-349.

Slater TF, Sawyer BC: The stimulatory effect of carbon tetrachloride and other halogenoalkanes on peroxidative reactions in rat liver fractions in $v i$ tro. Biochem. J. 1971, 123, 805-814.

Tarladgis BG, Pearson AM, Dugan Jr. LR: The chemistry of the 2-thiobarbituric acid test for the determination of oxidative rancidity in foods. Some important side reactions. J. Amer. Oil. Chem. Soc. 1962, 39, 34-39.

Tsuchıda M, Muira T, Shımuzu T, Aıbara K: Elevation of thiobarbituric acid values in the rat liver intoxicated by $\mathrm{T}-2$ toxin. Biochem. Medicine 1984, 31, 147-166.

Uchiyama M, Mihara M: Determination of malonaldehyde precursor in tissue by thiobarbituric acid test. Anal. Biochem. 1978, 86, 271-278.
Ueno Y, Nakajima M, Sakai K, Ishu K, Sato N, Shimada $N$ : Comparative toxicology of trichothec mycotoxins: Inhibition of protein synthesis in animal cells. J. Biochem. 1973, 74, 285-296.

Ueno $Y$, Matsumoto $H$ : Inactivation of some thiolenzymes by trichothecene mycotoxins from Fusarium species. Chem. Pharm. Bull. 1975, 23, 2439-2442.

\begin{abstract}
Sammandrag
Studier over trichotecen-stimulerad lipidperoxidation och trichotecenernas toxicitet hos djur.

Tre experiment har gjorts med moss, som har fått kanda mangder trichotecener $i$ fodret eller direkt $i$ magsacken. Lipidperoxidation i lever har påvisats med TBA-talet. Eftersom TBA-talet sallan gav pålitliga resultat, tillfogades till undersokningarna metoderna for lipidperoxider och total karbonyl. Forekomst av aldehyder och ketoner jamfordes in vivo och in vitro. De samma undersokningarna har gjorts på hòns, regnbågsforeller och talrika palsdjur som misstanktes for kronisk forgiftning orsakad av trichotecener. Som en fjarde parameter på trichotecenernas verkan har anvants koncentration av A-vitamin i levern. Vår undersokning har visat att lipidperoxidation ar associerad med trichotecenforgiftning. Det verkar som om T-2 toxin och narastående trichotecener kan fororsaka en kraftig lipidperoxidation $i$ djurens lever aven i små koncentrationer. Nar den gemensamma koncentrationen av DON och 3-AcDON var nara $200 \mu \mathrm{g} / \mathrm{kg}$ foder, framkallade den en tydlig lipidperoxidation $\mathrm{i}$ mósslever påvisad med TBA-talet. Speciell vikt skall fasstas vid att mycotoxinerna redan kan finnas 1 foder fore experimentet.
\end{abstract}

(Accepted December 20, 1988).

Reprint may be requested from: Aldo Rizzo, National Veterinary Institute, P.O. Box 368, SF-00101 Helsinki, Finland. 
